\title{
ENTREPRENEURSHIP AND JAPANESE INDUSTRIALIZATION IN HISTORICAL PERSPECTIVE
}

\author{
by \\ John P. Tang * \\ U.S. Bureau of the Census
}

CES 09-30 September, 2009

The research program of the Center for Economic Studies (CES) produces a wide range of economic analyses to improve the statistical programs of the U.S. Census Bureau. Many of these analyses take the form of CES research papers. The papers have not undergone the review accorded Census Bureau publications and no endorsement should be inferred. Any opinions and conclusions expressed herein are those of the author(s) and do not necessarily represent the views of the U.S. Census Bureau. All results have been reviewed to ensure that no confidential information is disclosed. Republication in whole or part must be cleared with the authors.

To obtain information about the series, see www.ces.census.gov or contact Cheryl Grim, Editor, Discussion Papers, U.S. Census Bureau, Center for Economic Studies 2K130B, 4600 Silver Hill Road, Washington, DC 20233, Cheryl.Ann.Grim@census.gov. 


\begin{abstract}
Studies of entrepreneurship in nineteenth century Japan typically focus on the activities of leading industrialists who founded large, family-owned conglomerates known as zaibatsu. These individuals do not conform well with the archetypal Schumpeterian entrepreneur, but this discrepancy may be more an issue of context than behavior. However, due to a lack of documentation for smaller independent firms, it is difficult to make this comparison. To broaden the scope of analysis, I use data drawn from corporate genealogies, which provide a more complete cross-section of entrepreneurial activity. This dataset of firm entry during the Meiji Period (1868-1912) covers a wide range of industries, allowing me to analyze aspects of Japan's early industrialization that heretofore have relied on anecdotal or case evidence. I also propose a game-theoretic model of entry appropriate for entrepreneurs in late developing economies that exploit the qualitative nature of these data.
\end{abstract}

Keywords: Meiji Japan, entrepreneurship, entry model, industrialization, late development, technology adoption, zaibatsu

JEL codes: N85, O14, O33

* The research in this paper was undertaken while the author was at the University of California, Berkeley. Any opinions and conclusions expressed herein are those of the author and do not necessarily represent the views of the US Census Bureau. The research in this paper does not use any confidential Census Bureau information. Many thanks to Barry Eichengreen and Christy Romer for detailed suggestions in preparing early versions of this paper. I also received many helpful comments from Jose Luis Garcia- Ruiz, Gabriel Tortella, and participants at the entrepreneurship workshop sponsored by Complutense University of Madrid. All errors are mine. 


\section{Introduction}

The Meiji Period (1868-1912) witnessed a remarkable transition for the Japanese economy, whose rapid development propelled the feudal agrarian nation to industrialized status by the period's end. Under the banner of "rich country, strong military," Japan's economy trebled in size between 1880 and 1913 and its armed forces won unexpectedly in its wars against China (1896) and Russia (1906). Investment in roads, railways, harbors, and communication infrastructure grew at 10 percent per year while overall industrial output grew fivefold. Institutions developed apace with the establishment of a central bank in 1882, promulgation of a constitution along western traditions in 1889, and the adoption of the gold standard in 1897. By 1899, Japan no longer had to recognize extraterritorial rights for foreign nationals and the country regained full tariff autonomy in 1911.

How did Japan overcome its late start? On the one hand, it has been argued that the government played a pivotal role in industrialization by seeding strategic sectors and providing both the infrastructure and institutions that would be the basis of subsequent development. ${ }^{1}$ Consistent with theories of late development, leaders of the Meiji Restoration considered public intervention necessary to mobilize financial resources for broad-based industrialization and to mitigate the short-term risk of unfamiliar and costly investment projects. Some of the government's achievements include the Japan's first modern manufacturing facility, the Tomioka Silk Filature; the first railway, between Tokyo and Yokohama; and the first domestic-built steamship in its Nagasaki shipyard.

Nevertheless, other scholarship places much more weight on the contribution of private entrepreneurs, given the failure of many public enterprises and the government's withdrawal from direct investment in the 1880s. ${ }^{2}$ Drawn from the ranks of former samurai and wealthy merchants, these early industrialists advocated the adoption of foreign technologies and business practices. The most visible among them were the founders of the zaibatsu conglomerates, whose ventures touched nearly every part of the prewar Japanese economy. Their business empires had the advantages of scale, diversified holdings, and private ownership to allow for efficient production, greater risk-taking, and investment autonomy. So dominant and pervasive

\footnotetext{
${ }^{1}$ See Nakagawa (1974) and Lockwood (1954).

2 See Morck and Nakamura (2007) and Tipton (1981).
} 
were the zaibatsu that some historians considered them to have been critical to Japan's successful industrialization. ${ }^{3}$

Yet this claim, like that of state-led growth, is difficult to assess due to a paucity of detailed firm-level data. This is unsurprising given the historical context and institutional environment, where even modern day developing economies lack the wherewithal to provide a comprehensive and accurate account of domestic entrepreneurial activities. This means little is known about smaller firms and non-strategic sectors populating much of the economic landscape, thus handicapping economic analysis with substantial biases and inferences of limited value.

Notwithstanding the lack of traditional sources of data measuring prices or output, it may still be possible to study entrepreneurship at an early stage of economic development. One commonly overlooked resource is the corporate genealogy, which traces the history of a firm from its establishment through changes in ownership up to its modern-day successor. While a genealogy contains much less information than that found in financial reports, industry surveys, and economic censuses, it can provide qualitative facts like date of founding, industry of operation, ownership type, even geographic location. Figure 1 shows an example of a corporate genealogy. ${ }^{4}$

This paper describes a newly constructed dataset that uses such a collection of corporate genealogies, the Shuyo Kigyo no Keifuzu (Genealogies of Major Corporations). ${ }^{5}$ These genealogies represent the oldest available sources of firm-level information that span the entire industrial spectrum as existed in late nineteenth century Japan. Compiled and edited by the business historians Shintaro Yagura and Yoshiro Ikushima, they are based on the corporate histories maintained by modern listed firms in Japan. With such broad coverage of economic activity, these genealogies make it possible to see some general contours of the economy as well as to address a number of longstanding questions about entrepreneurship in early modern Japan.

Supplementing this dataset is a simple model of industry entry. Considering that the amount of information provided by these genealogies is limited, I present a game-theoretic model that exploits the qualitative nature of the data. Furthermore, unlike most existing models of firm entry, this model can

\footnotetext{
${ }^{3}$ Morikawa (1992).

${ }^{4}$ Adapted from Yagura and Ikushima (1987).

${ }^{5}$ Ibid.
} 
be used to predict entrepreneurial behavior in a late development framework, characterized by the absence of industry incumbents and indigenous innovation.

The remainder of the paper is as follows: Section 2 provides some historical context for the emergence of modern entrepreneurial firms. Section 3 describes in greater detail the genealogical data used in this paper and some stylized facts that can be drawn from them. Section 4 presents the gametheoretic model, and Section 5 concludes.

\section{Meiji Period Entrepreneurs}

Who were the entrepreneurs that led Japan's economic development starting in the late nineteenth century, and what were the enterprises and industries they established? While independent, innovative entrepreneurs may have flourished in economies like the United States and Britain, they were much less noted in nineteenth century Japan. Arguably, this is due primarily to the country's late economic development, which meant that Meiji Japanese entrepreneurs could adopt pre-existing, foreign technologies without needing to make indigenous innovations. ${ }^{6}$

Gerschenkron's theory of late development asserts that there is an inverse relationship between a country's "backwardness" and its (potential) rate of economic growth. ${ }^{7}$ In other words, less advanced economies can leapfrog over intermediate technologies directly to the state-of-the-art by adopting the practices of the most advanced economies, saving themselves the time, effort, and expense required of earlier pioneers. Gerschenkron himself viewed Japan as a paradigmatic example of a developing country that through technology transfer and resource mobilization was able to converge with leading industrial nations in a short period of time.

But a backlog of foreign technologies is only part of the explanation. That is, the highly volatile external environment in which Meiji Japanese entrepreneurs found themselves may have obviated the need for innovative, disruptive technologies since investments in non-native technologies would

\footnotetext{
${ }^{6}$ It can be argued that adapting foreign technology to fit a different institutional and cultural setting is innovative as well, and those that did so reaped rewards similar to those in advanced economies.

${ }^{7}$ Gerschenkron (1962).
} 
have already entailed substantial risk. Meiji Japan may have been an ideal setting for the "mimetic entrepreneur," whose binding constraint was more financial than technological, as opposed to the archetypical "innovative entrepreneur." This is consistent with the Gerschenkron's backwardness hypothesis, which depends on the ability to marshal substantial resources to take advantage of modern technologies. Like most developing countries, Meiji Japan's financial infrastructure and capital markets were fairly immature, hindering the ability of entrepreneurs to obtain funding for their ventures.

Given these impediments, the study of modern Japanese entrepreneurship invariably returns to the role played the family-owned zaibatsu conglomerates in the nineteenth century, the six largest being Mitsui, Mitsubishi, Sumitomo, Yasuda, Furukawa, and Okura. ${ }^{8}$ As noted in previous studies, the entrepreneurs who established these industrial conglomerates had privileged access to government resources and/or substantial personal wealth to underwrite their business ventures. ${ }^{9}$ That said, this group was not monolithic in industry orientation or financial resources. The founder of the Mitsui zaibatsu was Hachirobei Takatoshi Mitsui, who began as a dry goods merchant in Kyoto, but later handled the collection and remission of government tax revenues. Iwasaki Yataro, who founded the Mitsubishi zaibatsu as a shipping company, had lucrative government contracts and protected trade routes. Soga Riemon, who changed his name to Sumitomo after his marriage to the daughter of Masamoto Sumitomo, operated the government's Besshi copper mine, the largest in the country. Zenjiro Yasuda, who founded the eponymous zaibatsu, was a financier to the central government and helped administer the redemption of government bonds. Kihachiro Okura was initially a grocer before becoming an official arms dealer for the government. And finally, like Sumitomo, Ichibei Furukawa operated lucrative copper and silver mines.

\footnotetext{
8 Mitsui, Mitsubishi, Sumitomo, and Yasuda were also collectively known as the "Big Four." While both Mitsui and Sumitomo began operations well before the Meiji Period, only during the Meiji Period did they and the other zaibatsu emerge as diversified conglomerates with national footprints. This group of Meiji-era zaibatsu differs from the group that emerged in the first quarter of the twentieth century, also known as shinko zaibatsu; see Frankl (1999). ${ }^{9}$ Kerbo and McKinstry (1995), p. 42.
} 


\section{Example: Mitsubishi and Japanese shipping industry}

It may come as a surprise that an island nation like Japan would not develop modern shipping and shipbuilding industries until the late 1800s. In fact, Japan had both, although its shipping industry was confined to domestic waters and its shipyards to construction of wooden ships no larger than 75 feet in length or 150 tons in weight. These limits were due to a series of isolation edicts at the beginning of the Tokugawa Period (1603-1868), where the ruling government under Shogun Tokugawa Iemitsu banned large ship construction in order to isolate the country from foreign influence and trade. Moreover, the development of these two industries and that of the Mitsubishi zaibatsu are closely intertwined.

The modern shipping industry began in 1870 with the establishment of Tsukumo Shokai, later renamed Mitsubishi Shipping Company. This company was the first of many in the Mitsubishi zaibatsu led by founder Iwasaki Yataro, and initially served to intermediate between foreign and native merchants as well as to procure foreign-built ships. Its 1875 inaugural overseas commercial route was between Yokohama and Shanghai, expanding rapidly along the coast, then to Mumbai in 1894, and to London, San Francisco, and Australia in $1896 .{ }^{10}$ In fact, Mitsubishi monopolized the overseas shipping industry until 1891, when Osaka Shipping Company extended its domestic postal shipping service to Korea.

While these early journeys were mainly for postal deliveries, the diversification of Mitsubishi meant that business increasingly was in the goods trade. However, strong competition with British and American shipping prevented Japan from developing large-scale international operations until World War I, which substantially decreased shipping capacity and left open market opportunities for Mitsubishi and its fellow Japanese shippers.

The lack of technology and facilities to build modern steel ships meant that the shipbuilding industry developed after the shipping industry, since the latter could and did import foreign-built ships for their

10 An earlier, non-commercial international voyage was in 1874, when the Meiji government commissioned Mitsubishi to transport military troops to Taiwan for a punitive attack on that island's aborigines. 
business in its early years. ${ }^{11}$ The advent of a modern shipyard industry came about in 1895, when the first steel steamship Suma Maru, at 1,522 tons, was built. ${ }^{2}$ This accomplishment was also at the hands of the Mitsubishi zaibatsu, which owned the Nagasaki Shipyard that built the vessel. ${ }^{13}$ Twenty-five years later, Japan had become the third largest shipbuilding nation, following the United Kingdom and the United States, with a fleet of 1,940 ships totaling almost 3 million gross tons in weight. The efficiency and advancement of this industry were such that by World War II, construction costs were a third less than its nearest rivals in Britain and Germany and half the cost of an equivalent American ship, savings which were driven primarily by low labor costs. Despite these rapid advances, engines and turbines to power these ships continued to be imported until after World War I. ${ }^{14}$

\section{Data and stylized facts}

Notwithstanding their differences, it is hard to claim that zaibatsu founders were representative of Japanese entrepreneurs as a group. A problem that remains, however, is the absence of credible information that can be used as a reference to compare these major players. In other words, little is known about the contributions of zaibatsu competitors who may have operated in non-strategic sectors or at a small-scale, or were located in peripheral regions of the country. Moreover, much of the older scholarship has focused on the sociological dimension of Meiji entrepreneurs such as their patriotism or social class and less to the economic motivation behind their endeavors. ${ }^{15}$

Data from corporate genealogies, on the other hand, can compensate for this information imbalance as well as clarify the breadth and depth of industrial activity in the economy as a whole. Like other family trees, these genealogies trace a firm to its origins and provide basic information like a date of establishment, ownership and source of setup finance, industry classification,

\footnotetext{
${ }^{11}$ Another constraint to the early development of the shipyard industry was a lack of domestic raw materials for construction. Fortunately, resources like iron ore and coal were available in Southeast Asia and northern China.

12 However, the first modern ship of notable size was built in 1898, called the Hitachi Maru at 6,172 tons.

13 The government first built this shipyard in 1871, but sold it to Mitsubishi in 1887.

14 Morikawa (1992); Travis (1945).

15 For example, see Hirschmeier (1964), Ranis (1955), and Sansom (1950). Yamamura (1968) also surveys Japanese-language studies and makes a similar assessment.
} 
and geographic location. ${ }^{16}$ Despite being less quantitative than financial measures, these data are sufficiently detailed to indicate relationships between specific sectors while controlling for the abovementioned characteristics. ${ }^{17}$

The dataset draws on the Shuyo compilation, which includes genealogies for 1,089 firms that were listed on the Tokyo Stock Exchange as of September 1984 , and cumulatively contain over 14,000 unique establishment observations dating back to the early nineteenth century or prior. ${ }^{18}$ While it may be impossible to eliminate bias from surviving historical records, these genealogies are a better representation of economic activity that what currently exists due to the inclusion of smaller, less well-known firms that otherwise would not be recorded. Furthermore, additional bias is mitigated in that the genealogies include not only all ancestor firms of those surviving to 1984, but also acquisitions and asset transfers from firms outside direct lineages. ${ }^{19}$ These short-lived firms, which otherwise would not appear in any other historical record, to an extent minimizes the issue of firm survivor bias. This is especially true for manufacturing, whether it be in textiles and machinery, which is usually the focus of research on industrialization. Unlike services, which may require little capital investment or equipment, manufacturing typically leaves behind assets that may be purchased by other manufacturers, thus increasing the chance that the previous owner will appear in the genealogies.

Industry identification is provided directly through the company name or descriptor annotated to the firm, with which I retroactively apply the codes given in the 1984 edition of the Standard Industrial Classification for Japan

\footnotetext{
16 Yagura and Ikushima (1986). Additional sources of data include firm financial reports from the Eigyo Hokokusho Shusei collection (Yushodo 1966); the 1984 edition of the Standard Industrial Classification of Japan, which provides industry codes for each observed establishment; the US Census of Manufactures from 1905, which provides labor and capital expenditures to measure differences in industry factor intensity; and various Japanese industry indices and firm case studies like Asia Research (1955), Dodwell (1975); Mitsubishi Public Affairs Committee (1990), Ohsono (1995), and Russell (1939).

${ }^{17}$ Not all the observations contain every piece of information, for example, some lack their establishment location. The discrepancies are apparent in the different sample sizes provided in the summary statistics.

18 Note the difference between establishment and firm, with the latter possibly including multiple establishments (like zaibatsu). Due to the breakdown by industry, firms with multi-industry production (e.g., zaibatsu) sometimes have their divisions identified individually.

19 The dataset currently contains only independent firm startup activity and does not indicate a firm's subsequent success or failure.
} 
(JSIC). ${ }^{20}$ Typically, company names in Japan are in three parts: personal/geographic name + industrial activity + industrial operation/facility (for example, Ishitsuka + Bottle Manufacturing + Factory), with the most common company names using a combination of the first two identifiers. Of course, there are some exceptions to the single-industry-per-establishment identification, excluding conglomerates. For example, Ueno Coach and Rail is classified as both in the Local Railway (JSIC 3-digit code 402) and Light Passenger Vehicle Transport (JSIC3 414) industries. Also, the move toward abbreviation, multiple personal names, and deletion of industrial activity has largely occurred in the post-World War II period.

Although the classification of Japanese industrial sectors did not begin until 1930 and has been revised a number of times since, retroactive classification can be rationalized based on the following reasons. First, a lack of an industrial classification system in the Meiji Period means retroactively applied codes do not alter the historical record. Second, industrial sector distinctions that were made in later years do not preclude the existence of those distinctions during the Meiji Period. Third, codes for industries that did not exist in the Meiji Period do not have to be used. Fourth, industries that existed in the past that do not appear in the 1984 system can be additively included without needing to change existing codes.

Having an industry classification allows one to assign relative capital intensities, assuming that Japanese entrepreneurs borrowed technologies and equipment in whole. This assumption seems reasonable given the number of foreign experts and even entire factories that the country imported during this period. Since capital expenditures and labor costs are available for contemporary American industries, which were often at the cutting edge of technological innovation at the time, these figures may be used to approximate their Japanese industrial equivalents. ${ }^{21}$

The genealogies also indicate the type of ownership for each establishment, including individual proprietorship, partnership (limited and unlimited liability), mutual association, and publicly listed entities (limited and unlimited liability). This information is particularly useful for assessing an

20 Statistics Bureau of Japan (1984). The Japanese SIC system resembles the now-defunct American SIC system in its hierarchical ordering of industries and level of detail.

${ }^{21}$ An alternative classification of sectors into "heavy," "light," and "non-manufacturing" was suggested by Japanese economic historian Henry Rosovsky (1967). For ease of exposition and inclusion of industries not found in historical American censuses of manufacturers, these are used to classify establishments in Table I. 
economy with an immature financial system, especially as there may be fewer advantages in the joint-stock approach to finance investment compared to internal or debt-based financing. Anecdotal evidence suggests that equityfinanced firms were constrained by their need to pay dividends, resulting in firms that remained small and undercapitalized. ${ }^{22}$ Furthermore, privatelyheld ownership may allow for longer-term investments since financing was neither subject to business cycle volatility nor reliant on investors unwilling to tolerate long gestations until the enterprise makes a profit.

This variable also addresses the issue of corporate monitoring, prominent in discussions of postwar Japanese conglomerates (although important in the prewar era as well). Prior to the adoption of the 1893 Commercial Code, which standardized incorporation procedures and defined fiduciary responsibilities, the limited ability of outside investors to monitor management and dominant owners may have hindered the public listing of firms (and thus created a market failure for investment). ${ }^{23}$ This is because while incorporation occurred as early as 1868, the lack of institutions governing business practice or protection of property rights remained until the $1890 \mathrm{~s}^{24}$ Together these observations suggest a positive correlation between private ownership and first entry.

With this set of characteristics, a general picture of the Japanese economy emerges, parts of which corroborate previous anecdotal assessments and others more surprising. Table I shows the number of observations and new industries available in the dataset, disaggregated by type of entrepreneurial firm (or government). New industries means those that had no establishments prior to 1868 as identified in the Shuyo collection or firm histories supplementing the dataset. ${ }^{25}$

Interestingly, a large majority of establishments are identified as being kabushiki kaisha, similar to western joint-stock corporations, despite the traditional emphasis on bank-financed industrialization in Japanese economic history. ${ }^{26}$ This is consistent with recent literature that suggests

\footnotetext{
${ }^{22}$ Morikawa (1992); Teranishi (1999). For example, many publicly-listed firms were run for short-term profit and were incorporated for a predetermined time period, between three to ten years; see Fruin (1992).

${ }^{23}$ Loenholm (1906).

${ }^{24}$ Rosovsky (1961).

${ }^{25}$ A list of new industries established in the Meiji Period can be found in the appendix in Tang (2007).

${ }^{26}$ Akiyama (1988).
} 
equity finance may have had a stronger role than previously assumed. Furthermore, although most studies of Meiji Japanese industry focus on either the heavier sectors (e.g., shipbuilding, machine tools) or exportoriented light sectors (e.g., textiles, food processing), it is notable that nonmanufacturing industries like financial and professional services represent about a third of all new industries.

Looking at entrepreneurial type, we notice that independent firms entered the bulk of new industries. They also favored publicly-traded ownership, which may have been due to a lack of private wealth or internal financing available to zaibatsu-affiliated firms. Between light and heavy manufacturing sectors, independent entrepreneurs preferred less capitalintensive industries. In both ownership and manufacturing type, the opposite holds true for zaibatsu-affiliates. This makes sense given the purported advantages of being a zaibatsu, with greater access to resources (and possibly government favoritism) to allow for privately-funded and capital-heavy investments. It is also interesting to note that while zaibatsu may have favored heavy industries over light, they entered even more nonmanufacturing sectors, which may be due to the commercial background of many of these entrepreneurs.

How reliable are these data? Assessing their accuracy and representativeness presents a conundrum since it is precisely because of the lack of firm-level data that one turns to alternative sources. Nevertheless, there exist some national-level statistics that may be used to compare against the data from the Shuyo. For instance, in the first half of the Meiji Period, the central government embarked on a national banking experiment modeled after the system found in the United States in the early 1800s. ${ }^{27}$ Of the 153 National Banks chartered by the Japanese government, 102 are found in the Shuyo collection. Another comparison is graphically shown in Figure 2, which plots the total number of registered financial institutions as recorded by the Bureau of Statistics against a running sum of similar financial startups from the genealogies. ${ }^{28}$ While the Shuyo genealogies contain about half the number given in national series, both series have remarkably similar trends and since the latter only contains startups a discrepancy with all financial institutions can be expected. This, in turn, suggests the data's appropriateness for use in entry considerations of entrepreneurial firms, which can be motivated by a new game-theoretic model of entry.

27 Soyeda (1994).

${ }^{28}$ Ohkawa (1987). 


\section{Model of entry}

Given the constraints faced by entrepreneurs in a late developing country like Meiji Japan and the limited amount of information available from corporate genealogies, it is not obvious whether existing models used to predict entry into new markets and competitive behavior would apply. For example, to predict the number of firms that enter into an industry, Bresnahan and Reiss (1987) rely on market size to calculate entry threshold ratios for different sectors. ${ }^{29}$ However, because the model focuses on the number of firms in an industry in equilibrium and compares industry incumbents with newcomers, it may not be appropriate for economies undergoing industrialization or for new sectors without incumbency. Nevertheless, having a formal framework that yields testable hypotheses despite limited information seems preferable to making generalizations from stylized facts. This motivates the game-theoretic model of entrepreneurial entry suggested below, which exploits qualitative differences between firms as opposed to absolute measures of production and prices.

Specifically, I propose a one-stage, simultaneous entry model with complete information and firm and industry differences. This model borrows features from the model of technology adoption by Fudenberg and Tirole (1985). For simplicity, I assume there are two entrepreneurs with access to identical technologies, although the number of investors can be generalized without difficulty. I also assume that there are two industries whose expected payoffs differ and are known prior to entry. Both assumptions are consistent for late developing economies that borrow technologies already in use abroad, but remain closed to foreign competition.

The difference between the two entrepreneurs is that one has access to greater financial resources, possibly due to pre-existing wealth or separate business operations. Since it is assumed that a late developing economy has imperfect financial markets, it seems reasonable that this relative difference is binding. Within the context of Meiji Japan, the wealthier entrepreneur is analogous to a former samurai with a lump-sum payment from the government in lieu of his hereditary stipend or a successful member of the merchant class expanding into a new sector. Both entrepreneurs can enter one of two industries, with the sectors differing in initial investment and

29 Berry (1992) uses a similar approach, but allows for firm heterogeneity and uses computer simulation for his estimates. 
commensurate payoff (i.e., safe versus risky). The wealthier entrepreneur has lower borrowing costs for external financing, which appears in his respective profit function. Thus, for the same level of investment in an industry, the poorer entrepreneur has to produce more to get the same return or, equivalently, earn a lower rate of return with the same level of output.

To produce at minimum efficient scale, a firm must have sufficient market share; in this two-agent model, profitable entry requires market monopolization while failure occurs when the two entrepreneurs enter the same industry and split market demand and/or compete on price. In a single period game, industry monopoly corresponds to first entry with all its attendant advantages (e.g., setting industry standards, cost reduction from learning). In either industry, if both entrepreneurs enter simultaneously and split the market, the poorer entrepreneur receives greater losses due to higher borrowing costs/funding constraints.

The payoff matrix in normal form is:

Entrepreneur B (poor)

\begin{tabular}{|c|c|c|c|c|}
\hline & & No entry & $\begin{array}{c}\text { Industry X } \\
\text { (safe) }\end{array}$ & $\begin{array}{c}\text { Industry Y } \\
\text { (risky) }\end{array}$ \\
\hline \multirow{3}{*}{$\begin{array}{l}\text { Entrepreneur A } \\
\text { (wealthy) }\end{array}$} & No entry & $(0,0)$ & $\left(0, \pi^{\mathrm{B}} \mathrm{X}, 0\right)$ & $\left(0, \pi^{\mathrm{B}_{\mathrm{Y}, 0}}\right)$ \\
\hline & $\begin{array}{c}\text { Industry X } \\
\text { (safe) }\end{array}$ & $\left(\pi^{\mathrm{A}} \mathrm{X}, 0,0\right)$ & $\left(\pi^{\mathrm{A}} \mathrm{X}, \mathrm{X}, \pi^{\mathrm{B}} \mathrm{X}, \mathrm{X}\right)$ & $\left(\pi^{\mathrm{A}} \mathrm{X}, \mathrm{Y}, \pi^{\mathrm{B}} \mathrm{Y,X}\right)$ \\
\hline & $\begin{array}{c}\text { Industry Y } \\
\text { (risky) }\end{array}$ & $\left(\pi^{\mathrm{A}} \mathrm{Y}, 0,0\right)$ & $\left(\pi^{\mathrm{A}} \mathrm{Y,X}, \pi^{\mathrm{B}} \mathrm{X}, \mathrm{Y}\right)$ & $\left(\pi^{\mathrm{A}} \mathrm{Y}, \mathrm{Y}, \pi^{\mathrm{B}} \mathrm{Y}, \mathrm{Y}\right)$ \\
\hline
\end{tabular}

where $\pi \mathrm{m}_{\mathrm{i}, \mathrm{j}}$ represents a profit function of the form

$$
\pi^{m_{i, j}}=p_{i}\left(q^{m_{i}}, q^{n_{j}}\right) \cdot q^{m_{i}}-c_{i}\left(q^{m_{i}}\right) \cdot q^{m_{i}}-\left(1+r^{m_{i}}\right) \cdot k_{i}
$$

for $\mathrm{m}, \mathrm{n}=\{\mathrm{X}, \mathrm{Y} \mid \mathrm{m} \neq \mathrm{n}\}$,

$$
i, j=\{A, B \mid i \neq j\} \text {. }
$$

Assume that:
a) $\pi^{\mathrm{m}_{\mathrm{Y}, 0}}=\pi^{\mathrm{m}_{\mathrm{Y}, \mathrm{X}}}>\pi^{\mathrm{m}_{\mathrm{X}, 0}}=\pi^{\mathrm{m}_{\mathrm{X}, \mathrm{Y}}}>0>\pi^{\mathrm{m}_{\mathrm{X}, \mathrm{X}}}>\pi^{\mathrm{m}_{\mathrm{Y}, \mathrm{Y}}} \quad$ for $\mathrm{m}=\{\mathrm{X}, \mathrm{Y}\}$

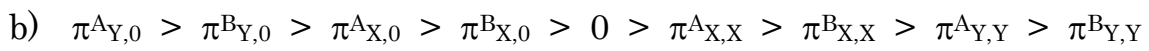
c) $\mathrm{r}_{\mathrm{i}}>\mathrm{r}_{\mathrm{i}}>0$
for $i, j=\{A, B \mid i \neq j\}$
d) $\mathrm{ky}>\mathrm{kx}>0$
for $i, j=\{A, B \mid i \neq j\}$ 
These relationships follow from differences between the two entrepreneurs and industries. They have the following interpretations: a) payoffs in each industry are positive (negative) and equal for either firm if it leads (shares) entry into a given industry, and are strictly higher for being the only entrant in the "risky" industry than in the "safe" industry; b) the wealthier entrepreneur receives higher profits (smaller losses) from single (shared) entry compared to the poorer entrepreneur; c) the poorer entrepreneur has a higher interest rate for borrowing capital than the wealthier one; and d) fixed costs for the "risky" industry are higher than the "safe" industry. ${ }^{30}$

It is readily seen that there exist two pure strategy Nash equilibria, when both investors enter different industries, and a mixed strategy equilibrium, when the two investors randomize entry between the two different industries. The pure strategy equilibria $\left\{\left(\pi^{\mathrm{A}} \mathrm{X}, \mathrm{Y}, \pi^{\mathrm{B}} \mathrm{Y}, \mathrm{X}\right),\left(\pi^{\mathrm{A}} \mathrm{Y}, \mathrm{X}, \pi^{\mathrm{B}} \mathrm{X}, \mathrm{Y}\right)\right\}$ arise because the best response for either entrepreneur to a potential rival's entrance into an industry is to enter the other industry. This is true regardless of the relative profitability of one's industry compared to his rival's. To not enter any industry is to forgo a positive payoff, while entering the same industry as one's rival would lead to a negative payoff.

The mixed strategy equilibrium can be derived by calculating the probabilities of entry in either industry by a rival. Let $\{a, b\}$ be the respective probabilities that the wealthier entrepreneur and his poorer counterpart will enter the "safe" industry. Then the former's expected total payoff across industries is:

$$
\prod^{A}=a \cdot b \cdot \pi^{A} X, X+a \cdot(1-b) \cdot \pi^{A} X, Y+(1-a) \cdot b \cdot \pi^{A}{ }_{Y, X}+(1-a) \cdot(1-b) \cdot \pi^{A} Y, Y .
$$

For the wealthier entrepreneur to be indifferent between choosing either the "safe" or the "risky" industry, the relative payoffs between the two choices must be:

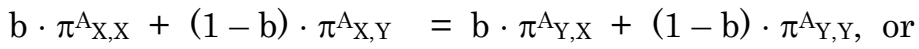

$$
\begin{aligned}
& \mathrm{b}=\left(\pi^{\mathrm{A}} \mathrm{T}_{\mathrm{Y}, \mathrm{Y}}+\pi^{\mathrm{A}} \mathrm{X}, \mathrm{Y}\right) /\left(\pi^{\mathrm{A}} \mathrm{X}, \mathrm{X}+\pi^{\mathrm{A}} \mathrm{Y}, \mathrm{Y}-\pi^{\mathrm{A}} \mathrm{X}, \mathrm{Y}-\pi^{\mathrm{A}} \mathrm{Y}, \mathrm{X}\right) \text { and } \\
& 1-\mathrm{b}=\left(\pi^{\mathrm{A}} \mathrm{X}, \mathrm{X}+\pi^{\mathrm{A}} \mathrm{Y}, \mathrm{X}\right) /\left(\pi_{\mathrm{X}, \mathrm{X}}^{\mathrm{A}}+\pi^{\mathrm{A}} \mathrm{Y}, \mathrm{Y}-\pi^{\mathrm{A}} \mathrm{X}, \mathrm{Y}-\pi^{\mathrm{A}} \mathrm{Y}, \mathrm{X}\right) .
\end{aligned}
$$

Similarly, probabilities of entry $(a, 1-a)$ for the wealthier investor must exist for the poorer entrepreneur to be indifferent between "safe" and "risky" industry types.

\footnotetext{
${ }^{30}$ Naturally, not entering either industry results in a zero payoff regardless of the action of one's competitor.
} 
The total expected payoff for the wealthier entrepreneur is increasing in $a$ if:

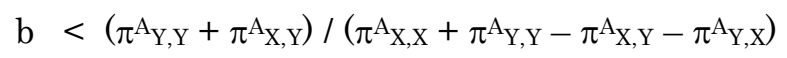

and vice versa. ${ }^{31}$ That is, the optimal response is for him to set $a=1$ (i.e., enter the "safe" industry) when the above inequality holds, and to set $a=0$ (i.e., enter the "risky" industry) when the inequality is reversed. When the above expression is an equality, then $a \in[0,1]$ is an optimal response.

The main result from this model is that entrepreneurs have asymmetric entry preferences due to differences in borrowing costs, which we have assumed to depend on differential access to private capital. Substituting in the profit functions shows that an increase in $r$ leads to an increase of the right-hand side of the above inequality, which allows for a larger $b$, ceteris paribus. This effect increases when the difference between the fixed costs $k_{i}$ for the "risky" and the "safe" industries is greater. In other words, a higher cost of borrowing increases the likelihood that the poorer entrepreneur will choose to enter the "safe" industry with lower fixed costs. Because single entry is more rewarding and shared entry is less costly to the wealthier entrepreneur, his expected total payoff is higher than that of his poorer rival when both randomize with the same probabilities. In this mixed strategy equilibrium, this translates to a greater likelihood that the wealthier entrepreneur will enter the "risky" industry relative to the poorer one (i.e., $a$ $<b)$. In the context of early modern Japan, the model predicts that entrepreneurs like capital-endowed ex-samurai or zaibatsu owners are more likely to lead entry into a new industry relative to their less well-endowed competitors. Note that the source of financing, whether from government bonds or revenues from other businesses, has no bearing on outcome so long as the effect on borrowing costs is the same, rendering non-economic distinctions such as an entrepreneur's "warrior spirit" irrelevant.

31 This expression is true only if the expected value of entry across industries is greater than or equal to zero; if less than zero, then the investor does not enter and his rival will choose the risky industry with certainty. See the appendix for the derivation of the equilibrium condition. 


\section{Conclusion}

While there has been considerable work assessing the contributions of individual entrepreneurs in the early modern period of Japan, it is largely limited to studies of individual firms and industries, or based on aggregate statistics that obscure differences between firms and entrepreneurial types. This paper describes a new firm-level dataset based on the corporate genealogies of major Japanese corporations, from which a few stylized facts emerge. First, it appears that equity-based financing may have played a greater role in Japan's early industrialization than previously credited, particularly for independent entrepreneurs. Furthermore, consistent with conventional wisdom, privately-financed and more-diversified firms appear to favor more capital intensive sectors, although their presence among nonmanufacturing industries was also substantial.

Besides these observations, having this new source of information on firms and entrepreneurs in Meiji Japan also allows one to test empirically for the first time some longstanding hypotheses about Japanese modernization that

previously relied on firm or industry case studies. For example, as mentioned earlier, one can begin to assess the relative performance of zaibatsu conglomerates against smaller, independent entrepreneurs. Since the genealogical data are more qualitative than most given their history, I present a game-theoretic model of entry appropriate for late developing countries. This model predicts a greater likelihood for better-endowed and/or diversified firms to engage in riskier entrepreneurial activities, although additional factors should be considered and a functional form be specified before one can evaluate this claim.

\section{References}

Akiyama, C. (1988). Talking Business in Japanese. Hauppauge, NY: Barrons Educational Series, Inc.

Asia Research (1955). An Outline of Japanese Industry. Tokyo: Ajia Kyokai.

Berry, Steven (1992). "Estimation of a model of entry in the airline industry." Econometrica 64(4): 889-917.

Bresnahan, Timothy and Peter Reiss (1987). "Do entry conditions vary across markets?" Brookings Papers on Economic Activity 1987(3): 833-881. 
Dodwell Marketing Consultants (1975). Industrial Groupings in Japan. Tokyo: Dodwell Marketing Consultants.

Frankl, Jennifer (1999). "An analysis of Japanese corporate structure, 19151937." Journal of Economic History 59(4): 997-1015.

Fruin, Mark (1992). The Japanese Enterprise System. Oxford: Clarendon Press.

Fudenberg, Drew and Jean Tirole (1985). "Preemption and rent-equalization in the adoption of new technology." Review of Economic Studies 52(3): 383401.

Gerschenkron, Alexander (1962). Economic Backwardness in Historical Perspective: A Book of Essays. Cambridge, MA: Harvard University Press.

Hirschmeier, Johannes (1964). The Origins of Entrepreneurship in Meiji Japan. Cambridge, MA: Harvard University Press.

Kerbo, Harold and John McKinstry (1995). Who Rules Japan? The Inner Circles of Economic and Political Power. Westport, CT: Praeger.

Lockwood, William (1954). The Economic Development of Japan, Growth and Structural Change. Princeton: Princeton University Press.

Loenholm, LH, ed. (1906). Commercial Code of Japan. Tokyo: Kokubunsha.

Mitsubishi Public Affairs Committee (1990). A Brief History of Mitsubishi. Tokyo: Mitsubishi Public Affairs.

Morck, Randall and Masao Nakamura (2007). "Business groups and the big push: Meiji Japan's mass privatization and subsequent growth." Enterprise and Society 3: 543-601.

Morikawa, Hidemasa (1992). Zaibatsu, The Rise and Fall of Family Enterprise Groups in Japan. Tokyo: University of Tokyo Press.

Nakagawa, Keiichiro (1974). "Business strategy and industrial structure in pre-World-War-II Japan." In Keiichiro Nakagawa (ed.), The International Conference on Business History: Strategy and Structure of Big Business 1. Shizuoka, Japan: Fuji Education Center.

Ohkawa, Kazushi, ed. (1987) Nihon Choki Tokei Soran [Long-term Historical Statistics of Japan]. Tokyo: Japan Statistical Association. 
Ohsono, Tomokazu (1995). Charting Japanese Industry. London: Cassell.

Ranis, Gustav (1955). "The community-centered entrepreneur in Japanese development." Explorations in Entrepreneurial History 8.

Rosovsky, Henry (1961). Capital Formation in Japan. New York: The Free Press.

Sansom, George (1950). The Western World and Japan, A Study in the Interaction of European and Asiatic Cultures. New York: Knopf.

Soyeda, Juichi (1995). A History of Banking in Japan. Surrey, UK: Curzon Press.

Statistics Bureau of Japan (1984). Standard Industrial Classification of Japan. Tokyo: Statistics Bureau of Japan.

Tang, John (2007). "The role of financial conglomerates in industry formation: evidence from early modern Japan." Center for Economic Studies Discussion Paper 07-32. Washington, DC: U.S. Bureau of the Census.

Teranishi, Juro (1999). "The main bank system." In The Japanese Economic System and its Historical Origins, ed. Tetsuji Okazaki and Masahiro OkunoFujiwara. Oxford: Oxford University Press.

Tipton, Frank (1981). "Government policy and economic development in Germany and Japan: A Skeptical Reevaluation." Journal of Economic History 41(1): 139-150.

Travis, Joseph (1945). The Shipping Industry of Japan. Washington, DC: Foreign Economic Association.

United States Census Bureau (1907). Manufactures. 1905 edition. Washington, DC: Government Printing Office.

Yagura, Shintaro and Yoshiro Ikushima (1986). Shuyo Kigyo no Keifuzu [Genealogies of Major Corporations]. Tokyo: Yushodo Publishing.

Yamamura, Kozo (1968). "A Re-examination of Entrepreneurship in Meiji Japan (1868-1912)." Economic History Review 21(1): 144-158.

Yushodo Publishing (1966). Eigyo Hokokusho Shusei [Business Reports Collection]. First series. Tokyo: Yushodo Film Publication. 


\section{Table I: Descriptive Statistics}

\begin{tabular}{|c|c|c|}
\hline & Establishments & Industries \\
\hline Entry in all JSIC4 sectors & 1,972 & 190 \\
\hline Entry in new JSIC4 sectors & 1,528 & 129 \\
\hline Government enterprise & 34 & 25 \\
\hline Zaibatsu-affiliated & 32 & 20 \\
\hline Independent & 1,462 & 112 \\
\hline \multicolumn{3}{|c|}{ Firm ownership in new JSIC4 sectors* } \\
\hline Publicly-traded & 1,253 & 92 \\
\hline Zaibatsu-affiliated & 140 & 4 \\
\hline Independent & 1,028 & 90 \\
\hline Non-traded & 252 & 65 \\
\hline Zaibatsu-affiliated & 6 & 17 \\
\hline Independent & 26 & 53 \\
\hline \multicolumn{3}{|c|}{ Capital intensity in new JSIC4 sectors * } \\
\hline Heavy industry & 117 & 50 \\
\hline Government enterprise & 14 & 10 \\
\hline Zaibatsu-affiliated & 8 & 7 \\
\hline Independent & 95 & 38 \\
\hline Light industry & 167 & 37 \\
\hline Government enterprise & 9 & 8 \\
\hline Zaibatsu-affiliated & 0 & 0 \\
\hline Independent & 158 & 35 \\
\hline Non-manufacturing & 1,244 & 42 \\
\hline Government enterprise & 11 & 7 \\
\hline Zaibatsu-affiliated & 24 & 13 \\
\hline Independent & 1,209 & 39 \\
\hline
\end{tabular}

Source: see text.

*: Not all genealogical entries have ownership information. Also, the industry breakdowns are not mutually exclusive; i.e., publicly-traded and non-traded firms can enter the same industry, as can zaibatsu-affiliated and independent firms. 
Figure I: Corporate Genealogy Example

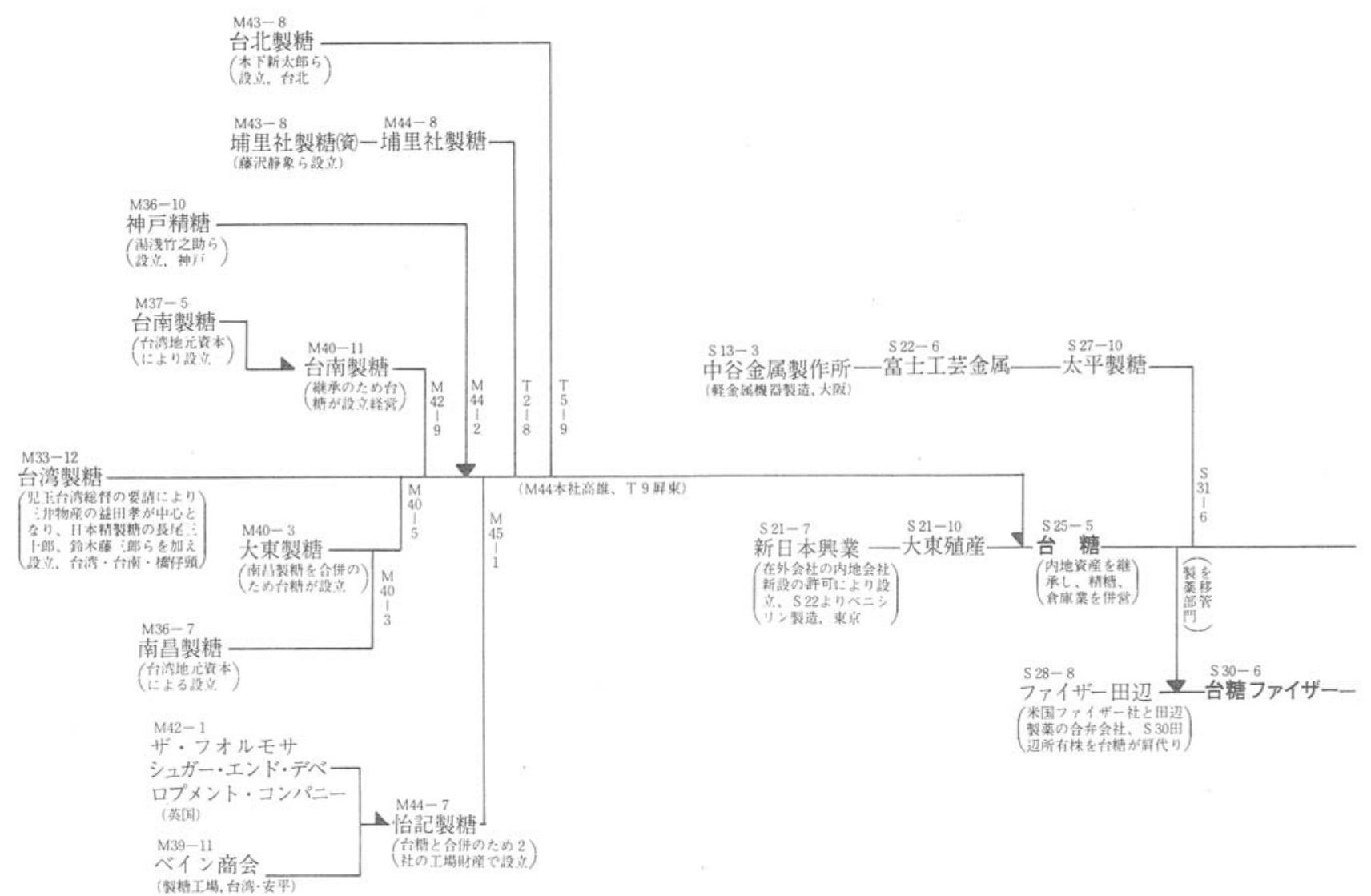

Source: Yagura and Ikushima (1986) 
Figure 2: Comparison of Financial Establishments Series

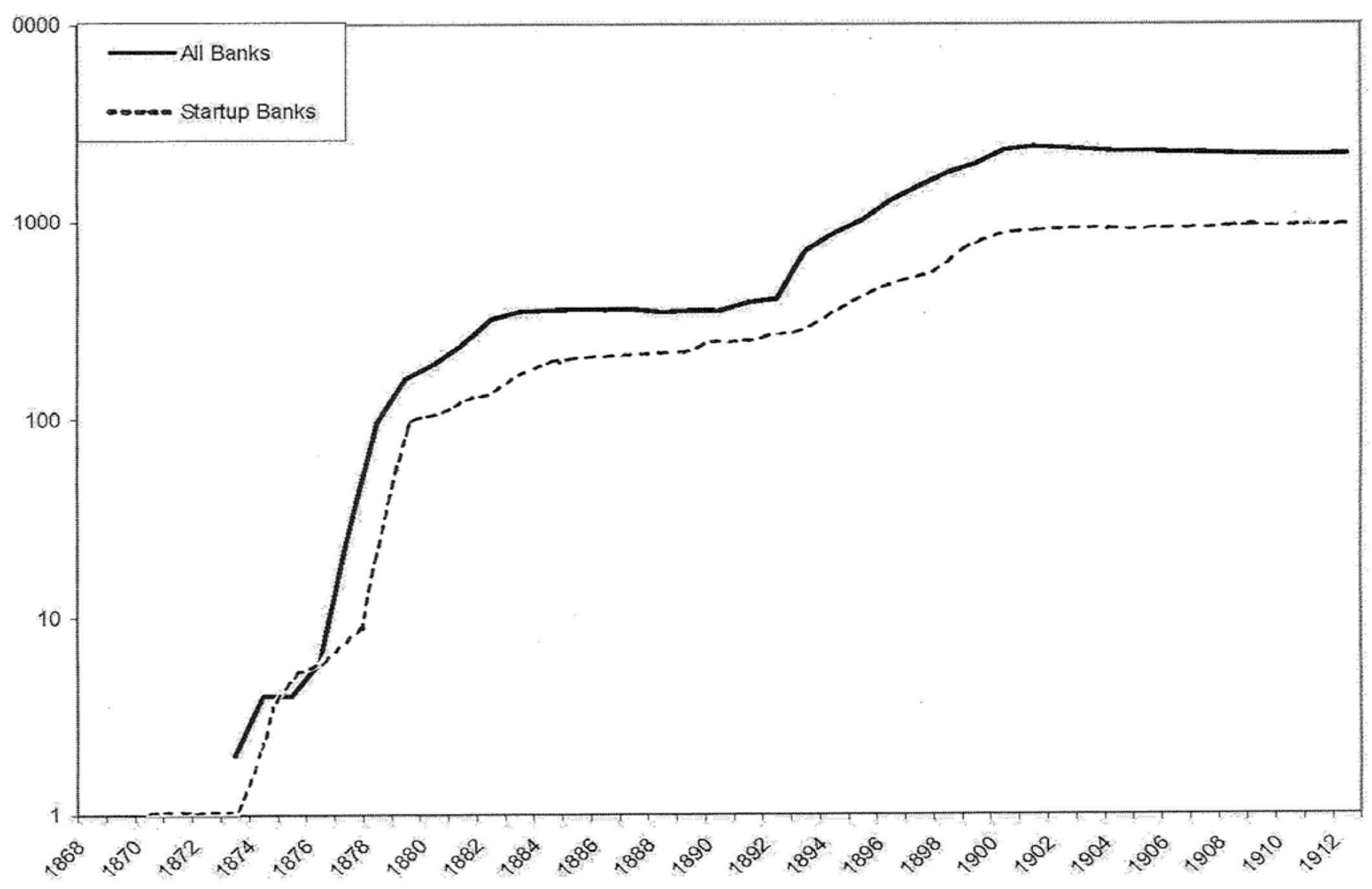

Source: see text 


\section{Appendix: Derivation of Entry Model Mixed Equilibrium}

The wealthy entrepreneur's expected total profit across both industries is:

$\Pi^{\mathrm{A}}=\mathrm{a} \cdot \mathrm{b} \cdot \pi^{\mathrm{A}} \mathrm{X,X}+\mathrm{a} \cdot(1-\mathrm{b}) \cdot \pi^{\mathrm{A}} \mathrm{X}_{\mathrm{Y}} \mathrm{Y}+(1-\mathrm{a}) \cdot \mathrm{b} \cdot \pi^{\mathrm{A}} \mathrm{Y}_{\mathrm{X}}+(1-\mathrm{a}) \cdot(1-\mathrm{b}) \cdot \pi^{\mathrm{A}} \mathrm{Y}, \mathrm{Y}$.

where $(\mathrm{a}, 1-\mathrm{a})$ are his probabilities of entry, respectively.

In addition, there are the following assumptions (explained in the text):
e) $\pi^{\mathrm{m}_{\mathrm{Y}, 0}}=\pi^{\mathrm{m}_{\mathrm{Y}, \mathrm{X}}}>\pi^{\mathrm{m}_{\mathrm{X}, 0}}=\pi^{\mathrm{m}_{\mathrm{X}, \mathrm{Y}}}>0>\pi^{\mathrm{m}_{\mathrm{X}, \mathrm{X}}}>\pi^{\mathrm{m}}, \mathrm{Y} \quad$ for $\mathrm{m}=\{\mathrm{X}, \mathrm{Y}\}$

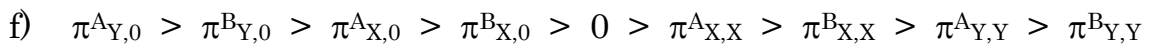
g) $\mathrm{r}^{\mathrm{B}_{\mathrm{i}}}>\mathrm{r}^{\mathrm{A}_{\mathrm{i}}}>0$
for $i, j=\{A, B \mid i \neq j\}$
h) $\mathrm{ky}_{\mathrm{Y}}>\mathrm{kx}>0$
for $i, j=\{A, B \mid i \neq j\}$

To be indifferent between the two industries, the wealthy entrepreneur's relative payoffs between both industries must be:

$$
b \cdot \pi^{A} X, X+(1-b) \cdot \pi^{A} X, Y=b \cdot \pi^{A} Y, X+(1-b) \cdot \pi^{A} Y, Y .
$$

That is, the expected payoff for choosing the "safe" industry must equal the expected payoff for choosing the "risky industry, conditional on the probabilities of entry for the poor entrepreneur. The above equation can be rewritten as the poor entrepreneur's relative probabilities:

$$
\begin{array}{ll}
\text { "safe" industry: } & b=\frac{\pi_{2,2}^{X}-\pi_{1,2}^{X}}{\pi_{1,1}^{X}+\pi_{2,2}^{X}-\pi_{1,2}^{X}-\pi_{2,1}^{X}} \\
\text { "risky" industry: } & 1-b=\frac{\pi_{1,1}^{X}-\pi_{2,1}^{X}}{\pi_{1,1}^{X}+\pi_{2,2}^{X}-\pi_{1,2}^{X}-\pi_{2,1}^{X}}
\end{array}
$$

For the wealthy entrepreneur to prefer the "safe" industry, the poor entrepreneur's probability of entry into the "safe" industry must satisfy:

$$
\text { "safe" industry: } \quad b<\frac{\pi_{2,2}^{X}-\pi_{1,2}^{X}}{\pi_{1,1}^{X}+\pi_{2,2}^{X}-\pi_{1,2}^{X}-\pi_{2,1}^{X}} .
$$

It can be shown that both the numerator and denominator are negative, which means the fraction overall is a positive value less than one. If the inequality holds, then the wealthy investor's payoff to enter the "safe" industry is increasing with a (and vice versa if the inequality is reversed). If both entrepreneurs randomize entry with equal probabilities by industry (i.e., $a=b$ ), then the wealthy entrepreneur earns a higher total expected payoff; 
equivalently, if both investors have the same expected payoff (e.g., zero-profit condition), then the wealth investor enters the "risky" industry with a greater probability than the poor entrepreneur (i.e., $a<b$ ).

If we substitute the profit functions in for the payoff terms, the inequality becomes:

$$
b<\frac{\left[p_{2}\left(q_{2}^{X}, q_{2}^{Y}\right) \cdot q_{2}^{X}-c_{2}\left(q_{2}^{X}\right)-\left(1+r_{2}^{X}\right) \cdot k_{2}\right]-\left[p_{1}\left(q_{1}^{X}, 0\right) \cdot q_{1}^{X}-c_{1}\left(q_{1}^{X}\right)-\left(1+r_{1}^{X}\right) \cdot k_{1}\right]}{\left[p_{1}\left(q_{1}^{X}, q_{1}^{X}\right) \cdot q_{1}^{X}-c_{1}\left(q_{1}^{X}\right)-\left(1+r_{1}^{X}\right) \cdot k_{1}\right]+\pi_{2,2}^{X}-\pi_{1,2}^{X}-\left[p_{2}\left(q_{2}^{X}, 0\right) \cdot q_{2}^{X}-c_{2}\left(q_{2}^{X}\right)-\left(1+r_{2}^{X}\right) \cdot k_{2}\right]}
$$

which means the inequality can be rewritten as:

$$
b<\frac{\left[p_{2}\left(q_{2}^{X}, q_{2}^{Y}\right) \cdot q_{2}^{X}-c_{2}\left(q_{2}^{X}\right)-\left(1+r_{2}^{X}\right) \cdot k_{2}\right]-\left[p_{1}\left(q_{1}^{X}, 0\right) \cdot q_{1}^{X}-c_{1}\left(q_{1}^{X}\right)-\left(1+r_{1}^{X}\right) \cdot k_{1}\right]}{p_{1}\left(q_{1}^{X}, q_{1}^{X}\right) \cdot q_{1}^{X}+p_{2}\left(q_{2}^{X}, q_{2}^{Y}\right) \cdot q_{2}^{X}-p_{2}\left(q_{2}^{X}, 0\right) \cdot q_{2}^{X}-p_{1}\left(q_{1}^{X}, 0\right) \cdot q_{1}^{X}}
$$

Assuming that the demand for goods is normal, we have the following relationship:

$$
p_{i}\left(q_{i}^{m}, 0\right) \cdot \geq p_{i}\left(q_{i}^{m}, q_{i}^{n}\right)
$$

which means both the numerator and the denominator are each negative and thus the entire fraction is positive, as asserted earlier. The interest rate $r$ appears only in the numerator, and is inversely proportional to the value of the entire fraction (i.e., a higher interest rate makes the numerator more negative). Therefore, at a higher interest rate, the wealthy entrepreneur's payoff to enter the "safe" industry also increase with a, ceteris paribus.

Notice also that interest rates do not need to differ even with different fixed costs. If there were a uniform interest rate $r$, then the above expression can be further simplified as:

$$
b<\frac{\left[p_{2}\left(q_{2}^{X}, q_{2}^{Y}\right) \cdot q_{2}^{X}-c_{2}\left(q_{2}^{X}\right)\right]-\left[p_{1}\left(q_{1}^{X}, 0\right) \cdot q_{1}^{X}-c_{1}\left(q_{1}^{X}\right)\right]+(1+r) \cdot\left(k_{1}-k_{2}\right)}{p_{1}\left(q_{1}^{X}, q_{1}^{Y}\right) \cdot q_{1}^{X}+p_{2}\left(q_{2}^{X}, q_{2}^{Y}\right) \cdot q_{2}^{X}-p_{2}\left(q_{2}^{X}, 0\right) \cdot q_{2}^{X}-p_{1}\left(q_{1}^{X}, 0\right) \cdot q_{1}^{X}} .
$$

This inequality indicates that even if borrowing costs do not differ, different fixed investment costs are sufficient to change entry probabilities. 